\title{
Kiat Mempertahankan Usaha Dalam Menghadapi Pandemi Covid-19 Bersama Para UMKM Di Meruyung Kota Depok
}

\author{
Eka Rahayu', Muhammad Faisal, Ahmad Alfarizi, Irawati, Riana Abdilah, Tri Sulistyani* \\ Prodi Manajemen,. Universitas Pamulang \\ ekadearahayu@gmail.com ${ }^{1}$,dosen01793@unpam.ac.id ${ }^{2 *}$
}

Received 25 April 2021| Revised 26 April 2021 | Accepted 26 April 2021

*Korespondensi Penulis

\begin{abstract}
Abstrak
Kegiatan pengabdian kepada masyarakat bertujuan untuk membantu Para UMKM untuk mempertahankan usahanya di tengah masa pandemi covid-19 agar tetap berjalan dan memperkecil kerugian bahkan sampai gulung tikar. Metode yang dilakukan yaitu pemaparan materi terkait kiat mempetahankan usaha di masa pandemi covid-19, pelatihan foto produk agar menarik konsumen dan pembagian sembako kepada Para UMKM di Meruyung, Kota Depok. Hasil yang diperoleh selama kegiatan ini, secara keseluruhan kegiatan pengabdian kepada masyarakat meliputi: materi, kejelasan materi yang disampaikan, fasilitator, tempat pelaksanaan, sajian/konsumsi mendapat respon baik dari seluruh peserta dan sangat membantu dan bermanfaat bagi peserta dalam mempertahankan usaha di masa pandemi covid-19.
\end{abstract}

Kata Kunci: Pandemi Covid-19; Para UMKM; Usaha

\begin{abstract}
Community service activities aim to help MSMEs to maintain their business in the midst of the Covid19 pandemic to keep going and minimize losses even to the point of bankruptcy. The method used is the presentation of material related to tips for maintaining business during the Covid-19 pandemic, training on product photos to attract consumers and distributing basic foodstuffs to MSMEs in Meruyung, Depok City. The results obtained during this activity, overall community service activities including: material, facilitators, place, and consumption received a very good response from all participants and were very helpful and beneficial for participants in maintaining their business during the Covid-19 pandemic.
\end{abstract}

Keywords: The Covid-19 Pandemic; MSMEs; Enterprises

\section{PENDAHULUAN}

\section{Analisis Situasi Permasalahan}

UMKM adalah singkatan dari Usaha Mikro, Kecil, dan Menengah. Dari sudut pandang pelaku usaha. UMKM bisa dideskripsikan sebagai bisnis yang dijalankan individu, rumah tangga, atau badan usaha ukuran kecil. UMKM (Usaha Mikro, Kecil, dan Menengah) adalah aktivitas usaha yang dilakukan oleh perorangan atau badan usaha milik perorangan. UMKM ini dapat ditemui dari pedesaan hingga perkotaan padat penduduk. Transaksi jual-beli memang sudah mendarah daging pada perekonomian di Indonesia. Bisa dikatakan bahwa kegiatan berdagang adalah sumber pendapatan terbesar bagi sektor perekonomian. Perkembangan UMKM di Indonesia termasuk cepat dan juga merupakan tongak perekonomi negeri ini.

Pandemi covid-19 di Indonesia pertama kali dideteksi pada 2 Maret 2020, ketika 2 orang terkonfirmasi tertular dari seorang warga Negara Jepang. Pada 9 April, pandemi sudah menyebar ke 34 provinsi dengan Jawa Timur, DKI Jakarta dan Sulawesi Selatan sebagai provinsi paling terpapar. Upaya pencegahan penyebaranpun dilakukan dan dikampanyekan. Setidaknya ada dua cara yang menjadi kunci pengendalian penularan dan penyebaran covid19 yaitu dengan menjaga jarak dan rajin mencuci tangan dengan sabun dan 
memperbanyak wastafel portable yang diadakan secara mandiri oleh masyarakat. Pemerintahpun akhirnya melakukan Pembatasan Sosial Berskala Besar (PSBB) serta mengkampanyekan Stay at home.

Sektor UMKM pun terdampak parah. Sektor UMKM yang paling terdampak yakni makanan dan minuman. Kementerian Koperasi dan UMKM mengatakan bahwa koperasi yang bergerak pada bidang jasa dan produksi juga paling terdampak pada pandemi Covid-19. Para pengusaha UMKM merasakan turunnya penjualan, kekurangan modal, dan terhambatnya distribusi. Dampak yang signifikanpun terjadi terhadap perekonomian di Indonesia. Dari semua lini usaha mikro, kecil hingga koperasi sangat terdampak dengan adanya wabah virus corona. Penjualan menurun, permodalan, pesanan menurun, kesulitan bahan baku, dan kredit macet. Ekonomi tiba-tiba ambruk dalam sekejap.

Sektor UMKM yang terguncang selama pandemi Covid-19 selain daripada makanan dan minuman, juga yang terdampak adalah industri kreatif dan pertanian. Bahkan hasil survey menunjukkan bahwa kesulitan yang belum pernah dihadapi perusahaan sebelumnya akibat pandemi covid-19, yaitu dua dari tiga perusahaan yang menghentikan operasinya baik sementara maupun secara permanen, karena pendapatan menurun drastis. Pandemi Covid19 memunculkan beberapa masalah bagi pelaku UMKM, di sisi lain ada kesempatan yang juga muncul. Pelaku UMKM bisa memanfaatkan teknologi informasi dan komunikasi mengingat perdagangan elektronik pada 2020 mengalami peningkatan yang signifikan. Produk yang penjualannya mengalami peningkatan, antara lain produk kesehatan meningkat $90 \%$, produk penunjang hobi naik $70 \%$, makanan naik $350 \%$, dan makanan herbal naik $200 \%$.

\section{Tujuan Pengabdian Kepada Masyarakat}

1. Memberikan pengetahuan tentang cara mempertahankan usaha di masa pandemi Covid-19

2. Memberikan pengetahuan tentang cara memasarkan produk agar menarik konsumen di masa pandemi Covid-19
3. Memberikan pelatihan cara pengambilan foto produk yang menarik konsumen

\section{METODE}

Sasaran peserta dalam kegiatan Pengabdian Kepada Masyarakat adalah para UMKM yang berada di wilayah Meruyung tepatnya di Jl. Tiga Putra Blok Singkuk Gg. Nusa Indah No. 18, Kelurahan Meruyung, Kecamatan Limo, Kota Depok, Jawa Barat. Adapun waktu pelaksanaan pada hari Minggu tanggal 07 Maret 2020 dimulai dari jam 09.00 - 12.00 WIB. Metode pelaksanaan yang dilakukan selama melakukan program ini melalui 2 tahapan. Pertama tahap pra pelaksanaan, meliputi survei untuk pemetaan masalah, survei kemitraan dan melakukan kerja sama dengan Para UMKM. Kemudian di tahap pelaksanaannya yaitu pemaparan materi terkait kiat mempetahankan usaha di masa pandemi covid-19, pelatihan foto produk agar menarik konsumen dan pembagian sembako kepada Para UMKM di Meruyung, Kota Depok. Setelah diadakan nya pemamparan dan pelatihan materi, Para UMKM dapat menerapkan cara mempertahankan usaha di masa pandemi covid-19.

\section{HASIL DAN PEMBAHASAN Hasil}

Hasil pelaksanaan PKM diukur berdasarkan jawaban peserta dengan tentang: materi PKM, kejelasan materi yang disampaikan, tempat pelaksanaan, sajian/ konsumsi selama pelaksanaan PKM yang diukur menggunakan penilaian skala 1 sampai 5 berikut:

Tabel 1. Penilaian Responden Terhadap Pelaksanaan Pelatihan

\begin{tabular}{ll}
\multicolumn{1}{c}{ Skor } & \multicolumn{1}{c}{ Kriteria } \\
\hline $4.21-5.00$ & Sangat Baik \\
\hline $3.41-4.20$ & Baik \\
\hline $2.61-3.40$ & Cukup \\
\hline $1.81-2.60$ & Kurang \\
\hline $1.00-1.80$ & Kurang Sekali \\
\hline
\end{tabular}

Tabel 2. Penilaian Responden Terhadap Pelaksanaan Pelatihan 
Jurnal Ilmiah Mahasiswa Mengabdi (JIMAWAbdi), Volume 1 Nomor 1, April 2021 (53-56) DOI: http://dx.doi.org/10.32493/jmwab.v1i1.10384

\begin{tabular}{llccccccccc}
\hline No & Penilaian Kegiatan & 5 & 4 & 3 & 2 & 1 & Jmh & Skor $\begin{array}{c}\text { Rata- } \\
\text { rata }\end{array}$ & Keterangan \\
\hline 1 & Materi PKM & 7 & 5 & 1 & 0 & 0 & 13 & 56 & 4.30 & Sangat Baik \\
\hline 2 & $\begin{array}{l}\text { Kejelasan } \\
\text { penyampaian materi }\end{array}$ & 5 & 8 & 0 & 0 & 0 & 13 & 57 & 4.38 & Sangat Baik \\
\hline 3 & Tempat pelaksanaan & 6 & 5 & 2 & 0 & 0 & 13 & 56 & 4.31 & Sangat Baik \\
\hline 4 & Sajian/Konsumsi & 2 & 8 & 3 & 0 & 0 & 13 & 51 & 3.92 & Baik \\
\hline & Kesimpulan Umum & 20 & 26 & 6 & 0 & 0 & 52 & 220 & 4.23 & Sangat Baik \\
\hline
\end{tabular}

5. Baik Sekali, 4. Baik, 3. Cukup, 2. Cukup, 1. Kurang Sekali

Berdasarkan hasil jawaban responden dari 13 peserta PKM pada tabel di atas, diperoleh hasil keseluruhan pelaksanaan pengabdian kepada masyarakat kiat mempertahankan usaha dalam menghadapi pandemi covid-19 rata-rata keseluruhan diperoleh nilai 4.23 dengan kriteria "sangat baik". Adapun urutan evaluasi pelaksanaan kegiatan pengabdian kepada masyarakat dari yang tertinggi hingga terendah meliputi: sajian/konsumsi dengan skor 3.92, materi PKM dengan skor 4.30, tempat pelaksanaan dengan skor 4.31 , dan kejelasan penyampaian materi dengan skor 4.38 .

\section{Pembahasan}

1. Materi PKM yang diberikan kepada peserta sangat baik karena materi disampaikan dengan jelas, mudah diikuti dan relevan dengan peserta.

2. Kejelasan penyampaian materi sangat baik dalam menguasai materi, cara/gaya penyampaian, dan kemampuan dalam menjawab permasalahan yang disampaikan oleh peserta.

3. Tempat pelatihan sangat baik, karena peserta merasa nyaman dalam mengikuti seluruh kegiatan dari awal sampai akhir.

4. Konsumsi yang disediakan baik.

Adapun dokumentasi kegiatan pengabdian kepada masyarakat seperti ditunjukkan pada gambar berikut:

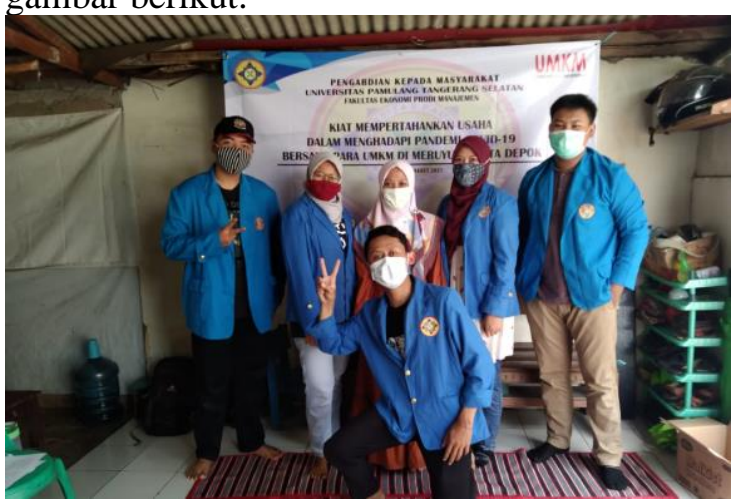

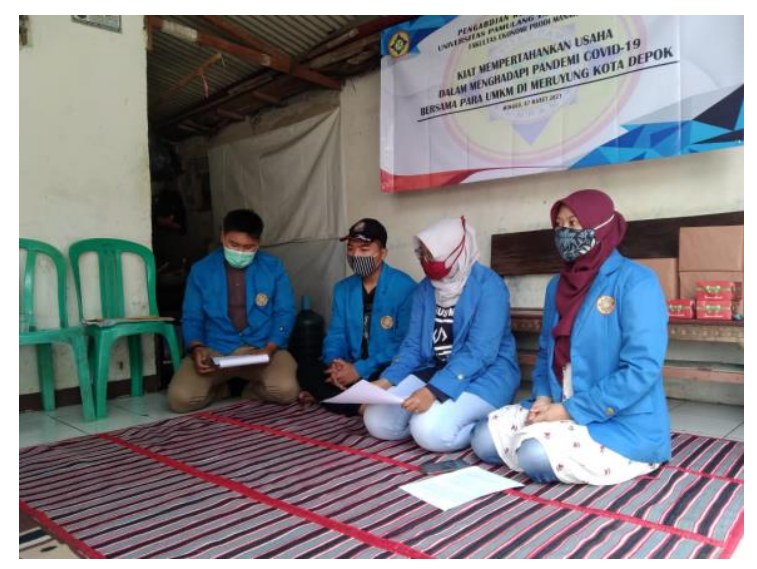

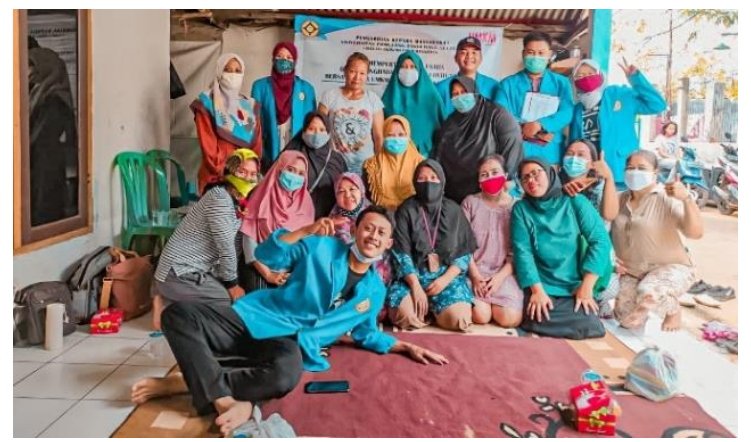

Gambar 1: Foto Kegiatan Pengabdian Kepada Masyarakat (Sumber: Dokumentasi)

\section{SIMPULAN \\ Kesimpulan}

Kegiatan pengabdian kepada masyarakat yang dilakukan di lingkungan Meruyung. Limo, Kota Depok, sangat bermanfaat bagi peserta dalam mempertahankan usahanya di tengah masa pandemi covid-19 agar tetap berjalan dan memperkecil kerugian bahkan sampai gulung tika. Oleh karena itu, kegiatan sejenis dapat dilaksanakan secara berkelanjut dengan penggali potensi yang dapat dikembangkan di lingkungan sekitar Meruyug, Limo, Kota Depok.

Secara keseluruhan kegiatan pengabdian kepada masyarakat ini meliputi: materi PKM, kejelasan materi yang disampaikan, tempat pelaksanaan, sajian/konsumsi mendapat respon 
sangat baik dari seluruh peserta. Sehingga kegiatan sejenis dapat terus dilaksanakan untuk membantu meningkatkan ekonomi usaha kecil dan menengah di lingkungan Meruyung, Limo, Kota Depok.

\section{Saran}

Perlu adanya kegiatan seperti ini berkelanjutan bagi masyarakat di lingkungan Meruyung, Limo, Kota Depok dengan beberapa masukan dari peserta:

1. Waktu kegiatan bisa di tambah/diperpanjang dan kegiatan bisa sering dilaksanakan

2. Materi yang diberikan lebih bervariasi lagi

\section{DAFTAR PUSTAKA}

Pengertian UMKM dan Perannya

https://www.akseleran.co.id/blog/umkm-adalah/ (diakses pada tanggal 13 Maret 2021, pukul 19.00)

Peraturan tentang undang-undang UMKM https://www.ojk.go.id/sustainable-finance/id/peraturan/undang-undang/Pages/Undang-Undang-RepublikIndonesia-Nomor-20-Tahun-2008-Tentang-Usaha-Mikro,-Kecil,-dan-Menengah.aspx (diakses pada tanggal 14 Maret, pukul 19.00)

Pernyataan covid-19 masuk ke Indonesia https://id.wikipedia.org/wiki/Pandemi_COVID-19_di_Indonesia (diakses pada tanggal 12 Maret 2021, pukul 17.00)

Sejarah UMKM di Indonesia

https://umkm.momsharing.id/sejarah-umkmdi-indonesia (diakses pada tanggal 13 Maret 2021, pukul 19.45). 